\title{
Globalisering en arbeidsverhoudingen
}

\author{
Kees Vos en Rob Gründemann*
}

Wat zijn de effecten van de globalisering op de nationale stelsels van arbeidsverhoudingen? Ter beantwoording van deze vraag wordt in deze bijdrage allereerst ingegaan op de betekenis van globalisering. Betoogd wordt dat er sinds de eeuwwisseling sprake kan zijn van een nieuw globaliseringparadigma. Vervolgens wordt ingegaan op de arbeidsverhoudingen in brede zin. Daarbij wordt geconstateerd dat als gevolg van de globalisering een neerwaartse concurrentie op arbeidsvoorwaarden en sociale bescherming plaatsvindt. De onderhandelingsagenda wordt steeds meer exogeen bepaald. Hierdoor dreigt functieverlies voor de actoren en instituties binnen de stelsels van arbeidsverhoudingen. Zolang de mening overheerst dat elk geneesmiddel erger is dan de kwaal, lijkt dit proces onomkeerbaar. Niettemin zijn nieuwe, corrigerende instrumenten noodzakelijk. Al was het maar om te voorkomen dat afnemende maatschappelijke en politieke steun voor globalisering uiteindelijk zal leiden tot een herlevend neoprotectionisme.

Trefwoorden: globalisering, internationale concurrentie, versobering van arbeidsvoorwaarden, medezeggenschap

\section{Inleiding}

'The days of the social partners are over.' Deze uitspraak van Roger Blanpain (2002) doelt op een fundamenteel functieverlies van de organisaties van werkgevers en werknemers op voor hen cruciale beleidsterreinen zoals belangenbehartiging en collectieve onderhandelingen. Ter verklaring wijst hij op de voortgaande decentralisering en individualisering van arbeidsrelaties. In deze bijdrage wordt betoogd dat deze observatie een kern van waarheid bevat, zij het dat in deze optiek het functieverlies niet (of niet uitsluitend) is te wijten aan decentralisering en individualisering. De oorzaak is in belangrijke mate (ook) gelegen in de effecten van globalisering: de spectaculair gegroeide, mondiale kapitaalcirculatie, de daarmee samenhangende groei van grensoverschrijdende fusies en overnames van bedrijven en de toenemende invloed van beleggingsfondsen. Deze blootstelling aan international market pressures for competitiveness (Streeck, 1998) heeft ingrijpende gevolgen voor de nationale arbeidsverhoudingen. Meer dan ooit beperken externe financieel-economische ontwikkelingen de beleidskeuzen en de onderhandelingsruimte voor de actoren binnen het stelsel van arbeidsverhoudingen.

Ter uitwerking van hetgeen hier schetsmatig is aangeduid, zal in het navolgende worden ingegaan op de effecten van globalisering op de nationale stelsels van arbeidsverhoudingen.

Daarbij hanteren wij een ruime invulling van het begrip arbeidsverhoudingen, ook omdat in de context van globalisering een breder perspectief op arbeidsverhoudingen

* Kees Vos is (onder meer) werkzaam bij TNO Kwaliteit van Leven/Arbeid. Correspondentieadres: TNO, Postbus 718, 2130 AS Hoofddorp, e-mail: kees.vos@tno.nl.

Rob Gründemann is (onder meer) werkzaam bij TNO Kwaliteit van Leven/Arbeid. Correspondentieadres: TNO, Postbus 718, 2130 AS Hoofddorp. 
wenselijk is (Macdonald, 1997). Bij de arbeidsverhoudingen gaat het dan niet alleen om de interacties tussen werknemers en management (vgl. Hyman, 1975), tussen organisaties van werkgevers en werknemers, inclusief de daaruit resulterende afspraken en instituties (vgl. Müller-Jentsch, 1997). Het betreft tevens de overheid als de external regulatory arm of labour relations (EF, 2002).

Ook de verschillende arena's (arbeidsmarkt, arbeidsorganisatie, sociale bescherming) waarin de actoren opereren kunnen daartoe worden gerekend, alsmede het wettelijke en institutionele beleidskader (EC 2002; EF, 2004). Onderhandelingsresultaten zijn niet alleen een functie van de interactie tussen de actoren (EF, 2002), maar worden tevens beïnvloed door de technologie, de marktvoorwaarden en de politieke context (vgl. Dunlop, 1958). Al met al omvat deze interpretatie wat als 'kern'-dimensies van de arbeidsverhoudingen beschouwd kan worden: context, actoren, processen en resultaten (vgl. Hay, 2000; EF, 2004; zie ook Vos, 2006). In deze bijdrage staat de vraag centraal naar de effecten van globalisering op de hier onderscheiden dimensies.

\section{De betekenis van globalisering}

De term globalisering raakte min of meer ingeburgerd aan het begin van de jaren negentig van de vorige eeuw. Sindsdien is het een onderwerp van voortdurende discussie geweest. Sommigen beschouwen het als een bron van economische welvaart, voor anderen is het de wortel van alle kwaad. Dit geeft al aan dat er uiteenlopende, soms elkaar aanvullende opvattingen over het begrip globalisering bestaan. Doorgaans blijkt er weinig consensus te bestaan met betrekking tot de vraag of de term een aanduiding is van een tijdperk in de geschiedenis, een proces, een theorie of een nieuw paradigma (Reich, 1998). De meeste literatuur op dit gebied is grosso modo te rangschikken naar drie invalshoeken.

In de eerste plaats is er de interpretatie van globalisering als een technologische en sociale revolutie. In deze opvatting, die bijvoorbeeld is terug te vinden bij Castells (1991) en Fukuyama (1992), leidt globalisering onvermijdelijk tot maatschappelijke convergentie omdat de technologische vooruitgang overal overeenkomstige economische en sociale ontwikkelingen teweegbrengt. Een dergelijke zienswijze is enigszins vergelijkbaar met de dertig jaar eerder verwoorde verwachting dat technologische en marktontwikkelingen zouden leiden tot uniformiteit of convergentie van de nationale stelsels van arbeidsverhoudingen (Kerr, Dunlop, Harbison \& Myers, 1960).

In de tweede plaats is er de visie waarbij globalisering vooral in verband wordt gebracht met de verbreiding van Amerikaanse waarden. Daarbij gaat het vooral om de intensivering van de internationale concurrentie, de international market pressures for competitiveness', en in het kielzog van de groeiende invloed van multinationale ondernemingen, de penetratie van het Amerikaanse model van corporate governance (zie bijvoorbeeld Höpner, 2001; Galgoczi, 2004), dat ondanks ENRON en andere schandalen nog steeds dominant is in Europese beleidskringen (Vitols, 2006).

In de derde plaats is er de opvatting waarbij onder de noemer van globalisering een groot aantal sociaaleconomische verschijnselen wordt gerangschikt. Ruigrok \& Van Tulder (1995) bijvoorbeeld associëren globalisering met de toegenomen mobiliteit van kapitaal, de toename van fusies, bedrijfsovernames en strategische allianties. In kringen 
rond de ILO worden globalisering en liberalisering van het kapitaalverkeer niet zelden geïdentificeerd met het ontstaan van sociale problemen op de arbeidsmarkt en in de arbeidsverhoudingen (Macdonald, 1997) en met de onmacht van de overheid om dergelijke sociale problemen aan te pakken (ILO, 1994; Gonzalez-Perez \& McDonough, 2007): 'this threatens to erode the socio-economic basis for national regulatory systems, labour relations, and trade union policies' (EF, 2002).

Niet alleen bestaan er uiteenlopende opvattingen over de invulling van het begrip globalisering, ook over de effecten lopen de meningen uiteen. Wat de impact van globalisering betreft, is er sprake van een 'sterke' versus een 'zwakke' globaliseringsthese (EF, 2002). Onder de voorstanders van een 'zwakke' these treft men verschillende van de auteurs aan die het accent leggen op de sociaaleconomische verschijnselen. Zij verwijzen bijvoorbeeld naar de door de jaren heen geringe groei van de wereldhandel: de wereldhandel in de zin van het aandeel van de export in percentage van het BBP was in 1870 gelijk aan het niveau van 1950 (5\%). Eerst na de totstandkoming van de General Agreement on Tariffs and Trade (GATT) in 1948 en de daarop volgende wereldhandelsconferenties groeit de handel tot een niveau van $17 \%$ rond de eeuwwisseling (vgl. Harman, 1996; Kol, 2001; EF, 2007a). Voorstanders van een 'zwakke' globaliseringsthese zijn voorts geneigd om de nadruk te leggen op de regionalisering, omdat het wereldhandelsverkeer zich voor $90 \%$ afspeelt in de triangle trade, de handel tussen de landen van de Europese Unie (EU), Noord-Amerika (NAFTA), Japan en Zuidoost-Azië (vgl. Ruigrok \& Van Tulder, 1995; Harman, 1996: Hay, 2000). Vóór deze opvatting spreekt dat inmiddels de helft van de wereldhandel en van het wereldwijde kapitaalverkeer in de EU plaatsvindt.

Tegenover de 'zwakke' staat een 'sterke' globaliseringsthese. Bamber, Lansbury \& Wailes (2004) spreken in hun beschouwing over de relatie tussen globalisering en arbeidsverhoudingen van een simple globalization approach: de internationale invloeden van de globalisering zijn zo overweldigend dat er maar weinig ruimte voor nationale verschillen overblijft. Vanuit de 'institutionalistische' zienswijze wordt deze benadering enigszins genuanceerd doordat verschillen in instituties op nationaal niveau kunnen leiden tot modificatie van internationale trends (vgl. ook Vos, 2007). Veel van de auteurs die de nadruk leggen op technologische en maatschappelijke ontwikkelingen, zijn hier te rangschikken. Naar onze mening is een combinatie van 'sterke' globalisering en institutionele modificatie het meest realistisch, ook al omdat het niet alleen, of zelfs niet zozeer, gaat om de kwantiteit van de input, maar vooral ook om de mate waarin waarden van marktliberalisering en competitiviteit op nationaal niveau zijn geabsorbeerd. Figuur 1 geeft de verschillende relaties nog eens schematisch weer. 
Figuur I Schematische weergave van de verschillende verbanden

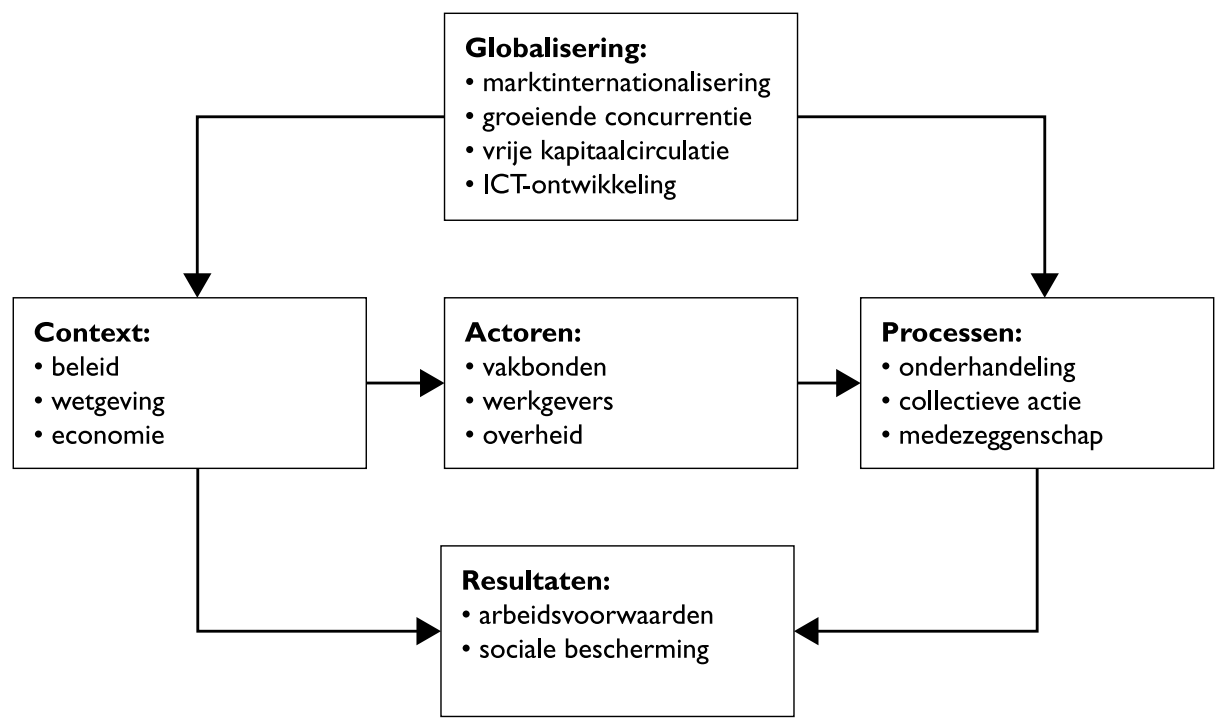

Bronnen: Kauppinen, 1994; Van Gyes et al., 2007; EF, 2007b; eigen bewerking

\section{Globalisering: een nieuw paradigma?}

In het licht van het voorgaande kan men de globalisering in drie fasen bezien. De eerste fase is de periode tot aan het eind van de jaren vijftig van de vorige eeuw, toen het mondiale handelsverkeer nog de belangrijkste component was. In de tweede fase zijn de technologische ontwikkelingen en de kapitaalcirculatie van doorslaggevend belang. In de derde fase, vanaf het eind van de vorige eeuw, raken niet-westerse landen, zoals China, India en Rusland, niet langer als vestigingsland maar ook en in toenemende mate als producent, dienstverlener en kapitaalverschaffer in het proces van globalisering betrokken. Naar aanleiding hiervan is er sprake van een nieuw globaliseringsparagdima (EF, 2007a). Ter verklaring zal hier worden ingegaan op een zestal achterliggende en/ of zich aandienende ontwikkelingen.

In de eerste plaats kan worden gewezen op de voortgaande ontwikkeling van de nieuwe technologie. Zoals de Wereld Commissie inzake de Sociale Dimensie van Globalisering (2004) heeft opgemerkt: 'The effects of the new technology have also given a distinctive character to the current process of globalization, as compared to similar episodes in the past. The natural barriers of time and space have been vastly reduced. The cost of moving information, people, goods and capital across the globe has fallen dramatically.'

Volgens de OECD (2007) maakt ICT het steeds gemakkelijker activiteiten, waaronder diensten die voorheen niet waren blootgesteld aan internationale concurrentie, over te plaatsen naar andere landen, met name landen als China en India. De verwachting is dat dit betrekking zal hebben op zo'n $20 \%$ van alle banen in de meeste industrielanden (Welsum \& Vickery, 2005). Daarbij zal de overplaatsing in belangrijke mate ook hooggeschoolde dienstverlening betreffen, alsmede specifieke taken binnen een bedrijf of bedrijfsonderdeel (EF, 2007). 
In de tweede plaats kunnen de nog steeds toenemende aantallen van grensoverschrijdende fusies en bedrijfsovernames worden genoemd. Binnen Europa zijn in de laatste twee decennia drie overnamegolven te onderkennen: een eerste golf rond 1990, in de slipstream van de actie 'Europa 1992', een tweede golf tegen het eind van de jaren negentig, in de aanloop naar de totstandkoming van de Economische en Monetaire Unie (EMU), waarbij de totale waarde van de transacties met $50 \%$ per jaar is gestegen, en een derde golf na het herstel van de beurskrach van 2001 en 2002. ${ }^{1}$ Door de fusies en overnames is wereldwijd het aantal multinationale ondernemingen in hoog tempo toegenomen: van ruim 7000 dertig jaar geleden naar thans 77.000 concerns met 770.000 vestigingen en 62 miljoen werknemers (UNCTAD, 2006). Ook Nederlandse bedrijven zijn in de laatste jaren nadrukkelijk in deze ontwikkeling betrokken, waarbij het jaar 2007 geldt als hoogtepunt in de Nederlandse uitverkoop (zie figuur 2).

Figuur 2 Overnames van of door Nederlandse ondernemingen in miljarden euro

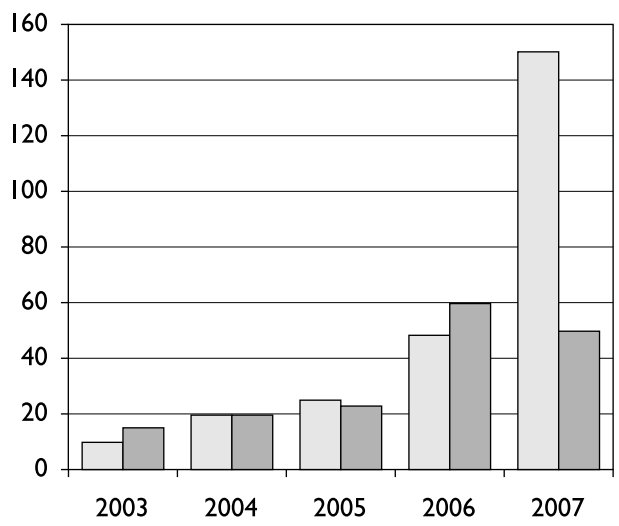

$$
\begin{aligned}
& \square \text { Buitenlandse overnames } \\
& \text { van Nederlandse bedrijven } \\
& \square \text { Buitenlandse overnames } \\
& \text { door Nederlandse bedrijven }
\end{aligned}
$$

Bron: NRC 26 maart 2008/RB/KPMG

Inmiddels is zo'n vier vijfde van de aandelen van Nederlandse AEX-bedrijven in handen van buitenlandse beleggers, terwijl bijna de helft van de bestuurders van buitenlandse origine is. Van de 432 grote industriële ondernemingen valt in 2005 58\% (met bijna een kwart van de werkgelegenheid in de industrie) onder buitenlandse zeggenschap (CBS, 2007). Elders in Europa is dat niet veel anders. In Hongarije is bijvoorbeeld $77 \%$ van de aandelen in buitenlands bezit, in België 53\% en in Frankrijk 39\%. ${ }^{2}$

In de derde plaats valt, min of meer in samenhang met het voorgaande, te wijzen op de rol van hedge en private equity fondsen, de zogenoemde durfkapitalisten. Naar schatting opereren er thans zo'n 8000 van dergelijke fondsen, die betrokken zijn bij ongeveer $20 \%$ van alle grensoverschrijdende overnames. In het algemeen beogen deze fondsen snelle transacties, kortetermijninvestering van hun vermogen met een tijdshorizon van vijf tot zes jaar (UNCTAD, 2006). Voor het afdekken van risico's maken deze fondsen, evenals ook banken, verzekeringsmaatschappijen en pensioenfondsen, 
gebruik van kredietderivaten. De onderliggende waarde van de kredietderivaten, dat wil zeggen al wat aan opties, rentecontracten en verhandelbare financiële contracten denkbaar is (bij wijze van spreken: handel op handel), vertegenwoordigt in 2007 een totale waarde van ruim 350.000 miljard dollar, drie à vier keer de werkelijke waarde van de gehele wereldeconomie. ${ }^{3}$ Gebleken is dat de snelle groei van de derivatenhandel grote risico's voor de financiële stabiliteit met zich meebrengt (DNB, 2005). In dit licht bezien kan men de huidige mondiale kredietcrisis dan ook vooral als het gevolg van een overwaardering van de bv Wereld beschouwen.

Ten vierde zijn in dit verband de voortgaande veranderingen in corporate governance van belang, de bestuursstructuur van bedrijven. Overname van Europese bedrijven door Amerikaanse of Angelsaksische multinationals heeft geleid tot inburgering van Amerikaanse corporate governance-principes. Tegelijkertijd leidt overname van Amerikaanse bedrijven door Europese concerns tot erosie van Europese bestuursvormen. Sinds de eeuwwisseling tot stand gekomen Europese regelgeving op dit gebied heeft tot resultaat dat de Amerikaanse shareholderbenadering vaste voet in Europa heeft gekregen (Van der Heijden, 2000).

Op basis van een onderzoek onder de 40 grootste beursgenoteerde ondernemingen in Duitsland heeft Höpner (2001) vastgesteld dat sinds het midden van de jaren negentig vooral die grootste Duitse ondernemingen, waarvan de aandelen in handen zijn van institutionele beleggers, zich in hun beleid in toenemende mate op het aandeelhoudersmodel oriënteren. Internationalisering leidt daarbij tot een snelle toename van de concurrentiedruk, ook ten aanzien van de arbeidsverhoudingen. In het algemeen wordt gesignaleerd dat Europese vormen van ondernemingsbestuur (het Rijnlandse model) vervangen dreigen te worden door Anglo-Amerikaanse governance-principes (Höpner, 2001; Galgoczi, 2004; Vitols, 2006). Daarbij gaat de groei van de aandeelhoudersmacht ten koste van de invloed van de andere belanghebbenden, de stakeholders, die meer dan voorheen aan de international market pressures worden blootgesteld.

Van een nieuw globaliseringsparadigma is met name ook sprake in relatie tot een vijfde, relatief recent element, namelijk de rol van nieuwe marktpartijen. In de afgelopen jaren is de omvang van de Chinese productie en van de dienstverlening vanuit India sterk gegroeid en het ligt in de lijn der verwachting dat deze groei zich in de toekomst zal voortzetten (EF, 2007b). Daarbij komt nog de toenemende invloed van de grote staatsfondsen van landen als China, Koeweit, Rusland, Saoedi-Arabië en Singapore. Het totale vermogen van de staatsinvesteringsfondsen wordt op een bedrag van 2,5 tot 3 biljoen dollar getaxeerd. Dit heeft de vrees doen ontstaan dat via dergelijke fondsen andere landen strategische sectoren in de Europese economie kunnen controleren. Verschillende landen overwegen om, in navolging van de VS en Frankrijk, wetgeving in te voeren ter blokkering van onwenselijk geachte bedrijfsovernames, terwijl EU-commissaris Peter Mandelson een gedragscode voor deze staatsfondsen heeft aangekondigd. Recent zijn de staatsfondsen overigens weer zeer welkom wanneer het erom gaat via investeringen in westerse banken de kredietcrisis op te lossen.

In de zesde plaats kan worden gewezen op ontwikkelingen in het Europese politieke krachtenveld. Wat de Europese landen betreft, bleef de opheffing van de handelsbarrières aanvankelijk beperkt tot de eigen regio. Gedurende een aantal jaren heeft de vorming van de Europese binnenmarkt in het teken gestaan van neo-mercantilistische opvattingen, gericht op de handhaving van 'fort-Europa': de realisering van een sterke 
regionale economie en de bescherming van de nationale arrangementen op het gebied van de sociale zekerheid (o.a. Van Apeldoorn, 2001). Vanaf het midden van de jaren tachtig is hierin een kentering gekomen, waarbij de toen ingezette actie 'Europa 1992' tot de ontsluiting van de Europese markt heeft geleid. In de aanloop naar de EMU heeft dit proces nog een extra impuls gekregen doordat de nationale restricties op grensoverschrijdende financiële transacties zijn afgeschaft. In dit opzicht kan men spreken van zowel een intra- als een interregionale afbouw van handelsbarrières, zodat de EU min of meer als een doorgeefluik voor de international market pressures is gaan fungeren. Vanwege de ambitie de EU uit te bouwen tot de meest concurrerende regio in de wereld levert de in 2000 vastgestelde Lissabon-strategie hiervoor vervolgens een beleidsmatige onderbouwing. Als middel ter vergroting van het concurrentievermogen wordt nadrukkelijk gewezen op de flexibilisering van de arbeidsmarkt en de modernisering van het Europese sociaal model (vgl. Huiskamp \& Vos, 2007). In de opvatting van de Europese Commissie (2004) is de kwaliteit van de arbeidsverhoudingen dan ook (grotendeels) afhankelijk van de mate waarin de sociale partners bereid zijn aan de realisering van deze sociaaleconomische beleidsdoelstellingen bij te dragen. Zoals Hyman (2001) in dat verband constateert: 'the process of European unification is often presented as marketization, as the necessary adaptation to globalization, with the corollary of economic adjustment, flexibility of labour markets, and the shrinkage of the welfare state'.

De hier genoemde ontwikkelingen zijn in veel opzichten bepalend voor de context waarbinnen de nationale stelsels van arbeidsverhoudingen functioneren. Daarmee wordt niet alleen de manoeuvreerruimte voor de nationale stelsels beperkt, maar worden ook de actoren, processen en resultaten direct dan wel indirect beïnvloed.

\section{Arbeidsverhoudingen en globalisering: het paard van Troje?}

Voor de West-Europese industrielanden kan gelden dat de stelsels van arbeidsverhoudingen tot stand zijn gekomen onder de relatieve bescherming van tariefmuren en handelsbarrières. Onderhandelingsprocessen en onderhandelingsresultaten reflecteren de manier waarop in de periode tot aan de jaren tachtig de onderlinge krachtsverhoudingen zijn geïnstitutionaliseerd. De ontmanteling van 'fort Europa' impliceert vervolgens een drastische verandering van de context waarin de nationale stelsels functioneren. Daarmee is niet gezegd dat nationale stelsels en instituties als zodanig zijn veranderd. Vergelijkend onderzoek geeft juist aan dat de instituties, althans voor wat de West-Europese landen betreft, een grote mate van stabiliteit vertonen (zie bijvoorbeeld Cortebeeck, Huys, Van Gyes \& Vandenbrande, 2005). Ondanks de sterk veranderende context blijven centrale instituties hun historische eigenheid behouden. Echter, internationalisering van het bedrijfsleven en toenemende blootstelling aan internationale concurrentie leiden ertoe dat beleidsmarges en beleidskeuzen op nationaal niveau steeds verder worden ingeperkt: 'the deregulation of financial markets and firms' strategies of internal and external flexibilisation enabling global sourcing threatens to erode the socioeconomic basis for national regulatory systems, labour relations, and trade union policies' (EF, 2002).

Met andere woorden: mede als gevolg van het Europese beleid is de deur wijd opengezet voor het Trojaanse paard van de globalisering. Externe, exogene dimensies beïnvloeden niet alleen de sociaaleconomische basis, maar ook de 'binnenkant' van de arbeidsverhoudingen: de actoren, processen en resultaten. In dit perspectief kunnen de volgende 
indicaties als symptomatisch worden beschouwd voor de veranderende krachtsverhoudingen.

\section{De veranderde positie van de actoren}

De beïnvloeding van de positie van de actoren op nationaal niveau wordt nog eens extra versterkt door Europese regelgeving en de EMU. Volgens Scharpf (2002) kunnen nationale overheden hierdoor alleen nog maar vrijelijk beschikken over en concurreren op beleidsmiddelen als belastingverlaging, deregulering van arbeidsvoorwaarden, toenemende loondifferentiatie en bezuiniging op verzorgingsarrangementen. Voor de vakbeweging impliceert dit 'concession bargaining', omdat zij zich genoodzaakt voelt lagere lonen of minder attractieve arbeidsvoorwaarden te accepteren teneinde bestaande werkgelegenheid te behouden.

Voor de vakbeweging mag voorts gelden dat de organisatiegraad de laatste tien jaar een dalende tendens vertoont. Zoals aangegeven in figuur 3 heeft de vakbeweging in vrijwel alle landen, maar met name in Oostenrijk, Ierland, Portugal, Duitsland en Griekenland, een aanzienlijk ledenverlies geleden, variërend van 20 tot 30\% (EF, 2007c).

\section{Figuur 3 Netto organisatiegraad van werknemers in EU 15 (\%)}

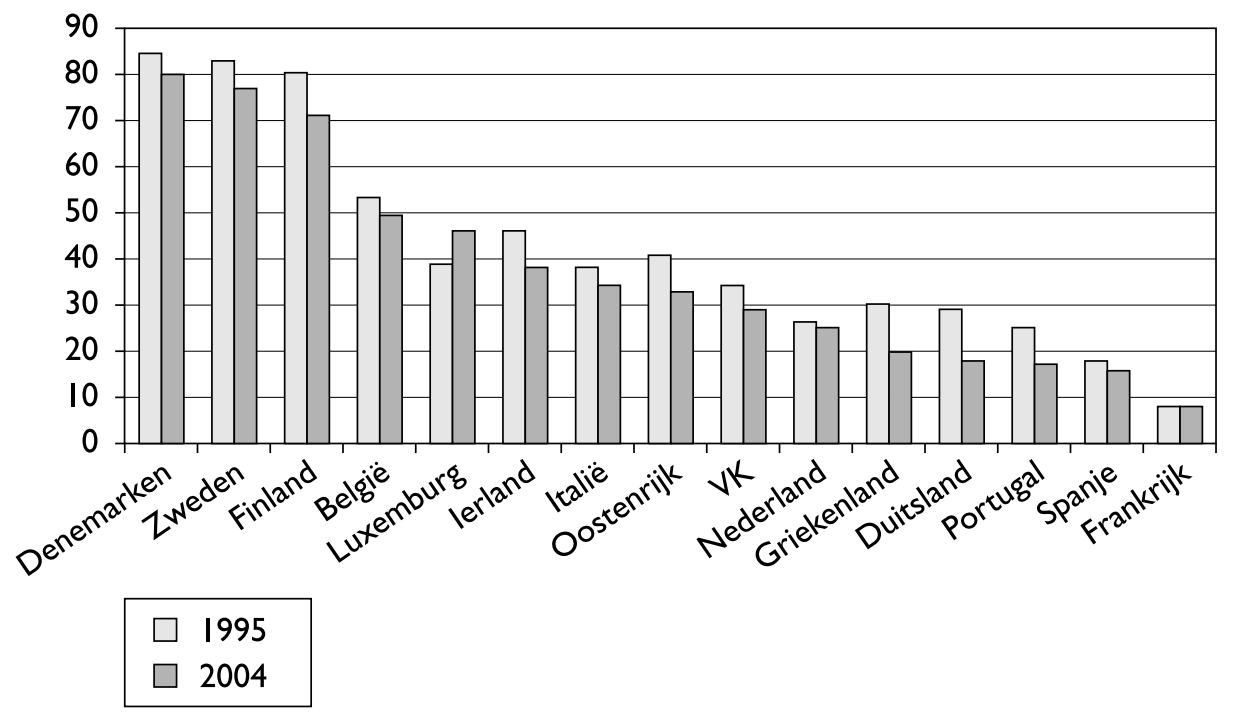

Bron: EIRO, Country profiles, 2006

Een van de oorzaken van het dalende ledental is de voortgaande deïndustrialisering, de overplaatsing van productieactiviteiten naar lage(re)lonenlanden. In de jaren zeventig en tachtig van de vorige eeuw kwam de internationale herverdeling van arbeid tot uiting in de afbouw van bedrijfstakken als de textiel, de scheepsbouw, ijzer en staal. Bovendien is in veel landen het traditionele patroon van een vaste, voltijdse arbeidsplaats goeddeels achterhaald. Hierdoor is de traditionele machtsbasis afgebrokkeld, terwijl de vakbeweging er onvoldoende in slaagt een sterke positie op te bouwen in de expanderende, met name dienstverlenende sectoren (zie ook Schilstra \& Smit, 2005). 
Voor de werkgevers geldt een wat hogere en meer stabiele organisatiegraad: van 55 tot $60 \%$ als gemiddelde over de EU27 (EF 2007b; EF 2007c). Nederland behoort op dit punt met $85 \%$ organisatiegraad tot de koplopers in Europa. Net als in de andere landen van de EU15 is de organisatiegraad in ons land betrekkelijk stabiel. De vraag is echter in hoeverre zoiets nog van betekenis is wanneer veel van de aangesloten grote ondernemingen eigendom zijn van anonieme kapitaalverschaffers elders in de wereld. In hoeverre zullen durfkapitalisten zich verbonden voelen met de tradities van onze overlegeconomie? In dit licht bezien valt niet uit te sluiten dat de centrale instituties van ons poldermodel worden uitgehold, omdat de werkelijke onderhandelingsagenda buiten hen om wordt afgehandeld.

\section{Veranderingen in medezeggenschap}

Het groeiend aantal grensoverschrijdende fusies en overnames is van invloed op processen van medezeggenschap en onderhandeling. Dit houdt verband met het feit dat, zoals figuur 4 aangeeft, een kwart van de werknemers in de Nederlandse industrie in dienst is van een buitenlandse werkgever. Dit geldt eveneens voor een groot aantal andere landen.

Figuur 4 Werknemers in de industrie met een buitenlandse werkgever, 2007 (\%)

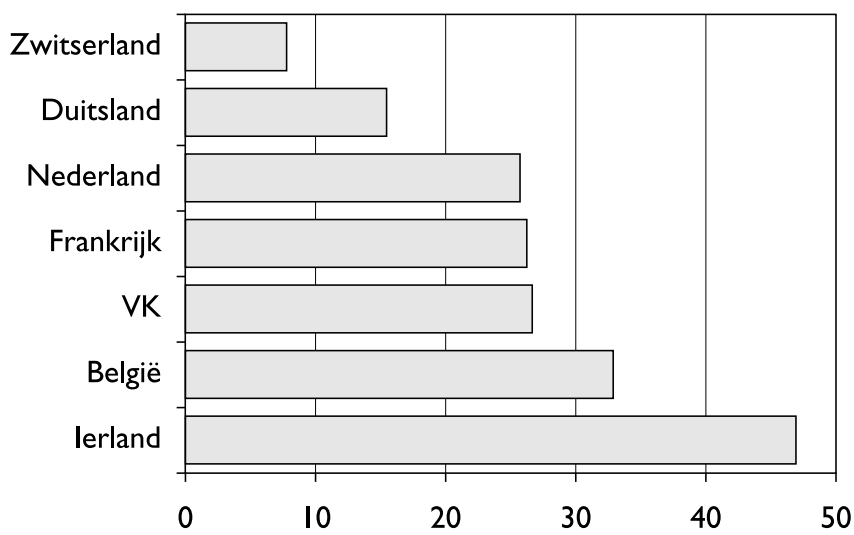

Bron: OECD/Elseviers Magazine

Vier vijfde van de aandelen van aan de Nederlandse AEX genoteerde ondernemingen is in buitenlandse handen. Daardoor hebben werknemers in het geval van een overname door een buitenlandse investeerder niet alleen te maken met andere overlegculturen, maar hun invloed kalft ook af door de toegenomen afstand tot het ondernemingsbestuur. In hoeverre kan nog sprake zijn van een sociale dialoog met in Londen, New York of Bermuda gevestigde eigenaars? Veelzeggend in dit verband is de uitspraak van een vertegenwoordiger van de Raad van Bestuur van Ahold, dat 'Nederlandse ondernemingsraden niet kunnen verwachten dat ze speciale rechten krijgen in bedrijven die $90 \%$ van hun omzet buiten Nederland maken en waar $85 \%$ van de werknemers in buitenlandse vestigingen werkt'. ${ }^{4}$

Door de verandering van de bestuursstructuur van de bedrijven, de 'corporate governance', zijn de rechten en bevoegdheden van de aandeelhoudersvergadering uitgebreid. 
Mede naar aanleiding van de acties van hedge en private equity fondsen zijn er publiekelijk vraagtekens gezet bij deze toegenomen aandeelhoudersmacht. In mei 2007 hebben de vakcentrales in een gezamenlijke brief aan SER-voorzitter Rinnooy Kan te kennen gegeven dat de SER advies dient uit te brengen over de zeggenschap binnen ondernemingen, omdat bij het nemen van strategische beslissingen de belangen van werknemers onvoldoende worden meegewogen. Blijkens het door de SER in februari 2008 uitgebrachte advies zijn in het geval van Nederlandse ondernemingen, die deel uitmaken van een internationaal concern, belangrijke besluiten op internationaal concernniveau inderdaad nauwelijks beïnvloedbaar vanuit de nationale medezeggenschapsregelingen. Volgens een deel van de Raad leidt dit ertoe dat medezeggenschap vergaand wordt uitgehold, tenzij er compensatie plaatsvindt via arrangementen voor internationale medezeggenschap. ${ }^{5}$ In dit verband denkt men met name aan de regeling van medezeggenschap bij fusie of overname via aanpassing van de richtlijn inzake Europese ondernemingsraden (zie SER, 2008).

Voorts is het de vraag in hoeverre een buitenlandse investeringsmaatschappij zich gebonden acht door bijvoorbeeld voorafgaand aan een bedrijfsovername uitonderhandelde concessies inzake behoud van werkgelegenheid. Vaak zijn dergelijke werkgelegenheidsgaranties van weinig waarde zodra het bedrijf wordt doorverkocht of de betrokken onderneming zorg moet dragen voor de financiering van de eigen overname (vgl. Wester, 2008). Wanneer inkrimping of bedrijfsbeëindiging onvermijdelijk is, gaan de sociale plannen meestal meteen in de prullenmand.

\section{Loonmatiging en ongelijkheid}

Naarmate er een groter belang wordt gehecht aan het concurrentievermogen, heeft dit een meer bepalende invloed op de resultaten, de 'output' van het stelsel van arbeidsverhoudingen. Voor ons land is de internationale concurrentie van oudsher een doorslaggevend punt van overweging geweest. Vrijwel vanaf de Tweede Wereldoorlog is onze open economie als argument gebruikt voor het handhaven van een gematigde loonontwikkeling. De destijds gehanteerde stringente loonpolitiek heeft tot resultaat gehad dat omstreeks 1960 de lonen in Nederland zo'n 20 à 25\% lager waren dan in Duitsland en België (Visser \& Hemerijck, 1998). En ook in later jaren is de concurrentie met het buitenland voor de overheid steeds een overweging geweest om in de loonvorming te interveniëren. Met het akkoord van Wassenaar in 1982 veranderde de door de overheid opgelegde soberheid in een zelfopgelegde soberheid. Voor sommigen was dat overigens nog niet goed genoeg. In zijn nieuwjaarsboodschap van 1997 schreef de toenmalige secretaris-generaal van Economische Zaken Geelhoed: 'Wat naar Europese maatstaven tamelijk goed lijkt, kan naar Amerikaanse of Oost-Aziatische maatstaven bepaald onvoldoende zijn.' Kennelijk was de tijd rijp om voor een inschatting van het nationale concurrentievermogen een stuk verder te kijken dan het ons omringende buitenland.

Er wordt in het algemeen niet aan getwijfeld dat de vele jaren volgehouden loonmatiging een belangrijke verklaring vormt voor het succes van het Nederlandse poldermodel. In de jaren negentig hebben althans verschillende andere landen in Europa het Nederlandse recept overgenomen. Mede tegen de achtergrond van de invoering van de EMU komen vrijwel overal sociale akkoorden tot stand, gericht op een gematigde loonontwikkeling in combinatie met het scheppen van werkgelegenheid. ${ }^{6}$ Tegelijkertijd is de 
EMU bij de vakbeweging aanleiding tot de (naar later zou blijken niet geheel ongerechtvaardigde) vrees voor een race to the bottom, een neerwaartse concurrentie op arbeidskosten tussen de Europese landen. Pleidooien voor Europese arbeidsvoorwaardencoördinatie zijn (onder andere) geconcretiseerd in de Doorn-declaratie van 1998, waar Belgische, Duitse, Luxemburgse en Nederlandse vakbonden overeenkwamen om loonconcurrentie tegen te gaan door de loonontwikkeling te koppelen aan de verhoging van de arbeidsproductiviteit. Uiteindelijk heeft dit geresulteerd in een gematigde loonontwikkeling in de landen van de Eurozone: terwijl de koopkrachtstijging in de jaren zestig van de vorige eeuw nog varieerde van 2,5 tot $7,1 \%$ per jaar, daalde deze in de jaren negentig tot tussen de 0,2 en $2,1 \%$ jaarlijks (EIRO, 2000). Voor de daaropvolgende jaren kan men spreken van een voortgaande convergentie in de gematigde loonontwikkeling (EIRO, 2006).

Wat de loonvorming betreft, is er dus een, op grond van concurrentieverhoudingen, gematigde stijging, zij het dat die stijging niet gelijkmatig is verdeeld. Volgens de OECD (2007) is het loonbestanddeel in het nationaal inkomen sinds 1980 in de meeste OECDlanden gedaald: "This means that average wage growth has not been keeping pace with the growth in labour productivity, even as trade and FDI have grown rapidly. This is consistent with globalisation having eroded the bargaining power of workers.'

Voorts wijst de OECD op de toename van de inkomensongelijkheid in de meeste OECDlanden, als gevolg van een daling van het inkomen van laaggeschoolde werknemers. Volgens de OECD is dit te verklaren uit een dalende vraag naar laaggeschoolden als gevolg van de overplaatsing van bedrijvigheid. Daarbij wordt niet uitgesloten dat globalisering een blijvend (negatief) effect zal hebben op het inkomensniveau en de arbeidsvoorwaarden van de lager geschoolde werknemers. Eerder (2003) had toenmalig Commissievoorzitter Prodi al vastgesteld dat de inkomensongelijkheid weer terug is op het niveau van dertig jaar geleden. Volgens de World Commission on the Social Dimension of Globalization (2004) bezit in de VS de qua inkomen top één procent van de bevolking in 2000 17\% van het BNP, een niveau dat voor het laatst was bereikt in de twintiger jaren van de vorige eeuw.

\section{Flexibilisering}

Ontwikkelingen in de Europese context hebben eveneens de 'output' van de arbeidsverhoudingen beïnvloed. In het kader van de Lissabon-strategie is de nadruk niet alleen gelegd op een gematigde loonontwikkeling, maar vooral ook op flexibilisering als middel om het concurrentievermogen in globaal perspectief op te voeren. Het resultaat hiervan is dat vrijwel overal vormen van flexibele beloning terrein hebben gewonnen. Steeds vaker varieert de loonsverhoging al naar gelang de resultaten van de nationale economie en/of van de eigen onderneming. Ook in ons land hebben werknemers van uiteenlopende functieniveaus een jaarinkomen met een variabel, prestatiegericht inkomensbestanddeel. Inmiddels krijgt bijna drie kwart van de werknemers in ons land een bonus in de vorm van prestatietoeslagen, verkoopcommissies, winstdeling en aandelen bovenop het vaste salaris. Volgens Buitendam (2001) maakt daarmee de naoorlogse 'zekerheidsbiedende beloningsstrategie' plaats voor een 'verzilveringsstrategie'. Kennelijk wordt variabele, resultaatafhankelijke beloning niet langer als een taboeonderwerp beschouwd. 
De oproepen tot flexibilisering van de arbeid hebben voorts in zoverre resultaat gehad dat sinds 2000 vormen van tijdelijk en/of deeltijdwerk in diverse Europese landen zijn toegenomen. Tijdelijke arbeidsovereenkomsten in de EU-25 zijn gegroeid van 11,7\% in 1998 naar 14,2\% in 2005. Deeltijdwerk is in deze periode toegenomen van 15,9 naar $18,5 \%$. Bovendien werkt intussen bijna de helft van de Europese werknemers in bedrijven met tien of meer werknemers in flexibele arbeidstijdschema's (EC, 2006). Zoals figuur 5 laat zien zijn er aanzienlijke verschillen tussen de Europese landen: Nederland is van oudsher de deeltijdkampioen in Europa, terwijl Spanje vooral veel werknemers in tijdelijke dienst heeft.

\section{Figuur 5 Flexibel werk in een aantal EU-landen in 2005 (\% van de beroepsbevolking)}

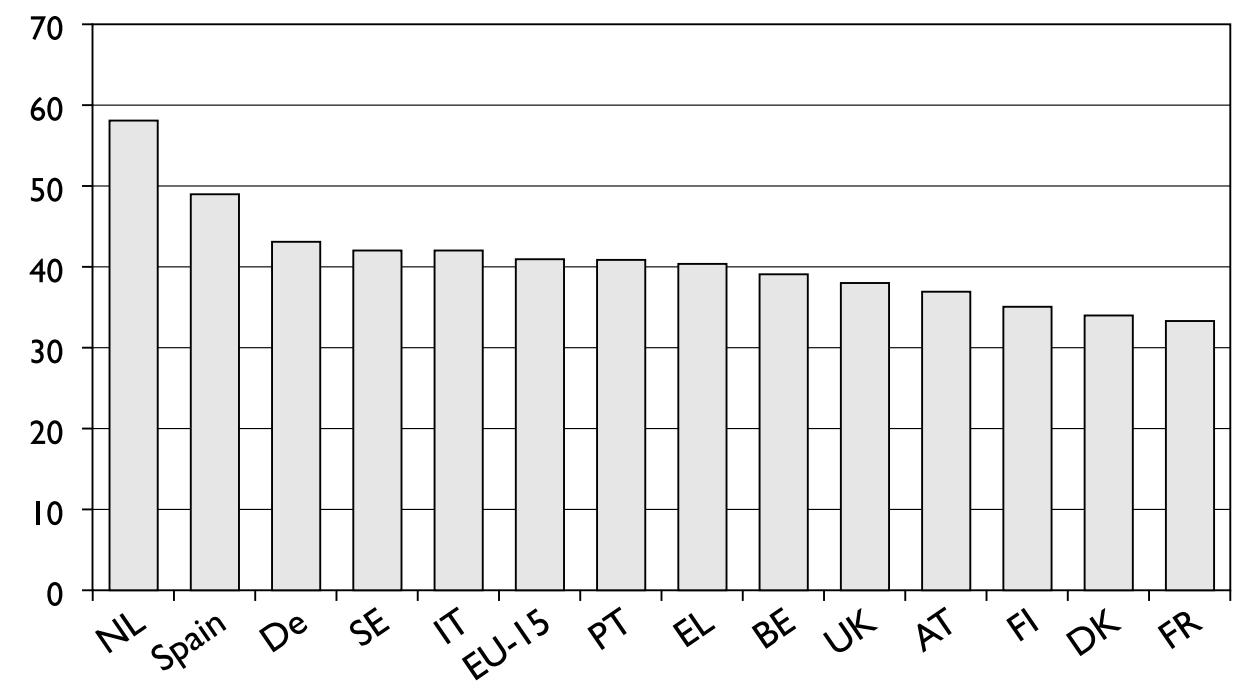

Bron: EU, LFS. N.B.: EU-I5 met uitzondering van lerland en Luxemburg

Om een tegenwicht te bieden tegen de mogelijke erosie van sociale bescherming als gevolg van de flexibilisering en deregulering van arbeid en arbeidsmarkt is eerst in Nederland en Denemarken, later op Europees niveau het concept van flexicurity geïntroduceerd. Het idee achter dit concept is dat via vier ingrediënten, namelijk de beschikbaarheid van contractuele regelingen, actieve arbeidsmarktpolitiek, geloofwaardige stelsels van leven-lang-leren en moderne stelsels van sociale zekerheid, een balans tussen flexibiliteit en zekerheid kan worden bereikt (EC, 2005). Uit internationaal vergelijkend onderzoek op dit gebied is inmiddels gebleken dat er veeleer sprake moet zijn van een onbalans: 'the more flexible employment, the more it is precarious' (Tangian, 2006; Seifert \& Tangian, 2007).

Samenvattend kan worden vastgesteld dat Europa in de afgelopen decennia de deur wagenwijd heeft opengezet voor het Trojaanse paard van de globalisering. Actoren, processen en resultaten van de arbeidsverhoudingen staan onder druk, terwijl de onderhandelingsagenda in nog steeds toenemende mate exogeen wordt bepaald. Het gevolg is dat het maatschappelijk draagvlak voor globalisering steeds verder afneemt. Beschouwt in 2003 nog een meerderheid (56\%) van de Europeanen (EU15) globalisering nog als positief voor de werkgelegenheid en het bedrijfsleven, in 2006 is dit gedaald tot $39 \%$. Tegelijkertijd beschouwt bijna de helft (48\%; in Frankrijk zelfs ruim $70 \%$ ) 
globalisering als bedreigend voor de werkgelegenheid en het bedrijfsleven (Eurobarometer 2003, 2006). In ons land blijkt $70 \%$ van de bevolking het opkopen van Nederlandse bedrijven als een groot probleem te zien. ${ }^{7}$ In combinatie met de groeiende invloed van staatsinvesteerders is dit voor de OECD (2007) aanleiding de vrees uit te spreken dat in de nabije toekomst ook de politieke steun voor globalisering kan verdwijnen.

\section{Besluit}

De zorg om het verdwijnen van maatschappelijke en politieke steun houdt verband met de vrees voor een herlevend neo-protectionisme. Een aantal signalen wijst inmiddels in die richting. In België is de overnamegolf van bedrijven aanleiding geweest tot een 'verankeringsdebat' in de jaren negentig: is een onderneming (nog) in Belgische (of Vlaamse) handen? In Frankrijk, Italië en Spanje hebben bedrijfsovernames geleid tot industriepolitieke initiatieven gericht op het stimuleren van 'nationale kampioenen', bedrijven van strategisch belang die niet in buitenlandse handen mogen vallen, terwijl in Duitsland de onlangs aangekondigde overplaatsing naar Roemenië van Nokia een brede maatschappelijke discussie op gang heeft gebracht. Ook bedrijven, zoals bijvoorbeeld de Europese vliegtuigbouwer EADS, overwegen de introductie van een 'gouden aandeel' voor de Franse en Duitse staat om de aankoop van een belang van meer dan $15 \%$ door derden (zoals het investeringsfonds Dubai International Capital en de Russische staatsbank VEB) te kunnen blokkeren. In ons land hebben PvdA en CDA al voor beschermende maatregelen tegen ongewenste overnames gepleit. Bovendien heeft de regering onlangs aangekondigd excessieve beloningen bij verkoop van de eigen onderneming aan banden te willen leggen, een initiatief dat tot voor kort nog vrijwel ondenkbaar was. Mede in het perspectief van de huidige kredietcrisis lijkt het tij dus enigszins te keren, hoewel er doorgaans nog weinig aandrang bestaat de bakens echt te verzetten. Als het er op aankomt, blijft als uitgangspunt gelden dat elk geneesmiddel erger is dan de kwaal. Dat laatste geldt zeker wanneer het de arbeidsverhoudingen betreft.

Zijn de dagen van de sociale partners dan inderdaad geteld? Niet wanneer men uit wil gaan van de institutionele continuïteit van de arbeidsverhoudingen. In recente (vergelijkende) analyses van nationale stelsels van arbeidsverhoudingen wordt nog vrijwel steeds uitgegaan van de institutionele vormgeving, zoals deze onder de relatieve bescherming van tariefmuren en handelsbarrières tot stand is gekomen. Met het wegvallen van die bescherming bepalen echter niet langer de onderlinge machtsverhoudingen op nationaal niveau, maar in toenemende mate de internationale concurrentieverhoudingen de functievervulling door nationale instituties. In analyses wordt hiermee tot dusverre relatief weinig rekening gehouden. Bovendien wordt er (te) weinig rekening mee gehouden dat de veranderende krachtsverhoudingen ook noodzaken tot de introductie van andere instrumenten. Zoals in kringen van de ILO is vastgesteld: 'Deeper economic globalization will require greater governance capacity' ( Gereffi, 2005). Dit geldt temeer omdat, zoals Van der Veen (2004) in ander verband heeft opgemerkt, de effectiviteit van het openbaar bestuur wordt aangetast, 'omdat beleidsvraagstukken zich steeds meer uitstrekken over domeinen waar de nationale staat geen of slechts beperkte of gedeelde zeggenschap heeft'. Doordat de onderhandelingsagenda meer en meer exogeen wordt gedetermineerd, dreigt ons poldermodel gereduceerd te worden tot een overlegfaçade voor een van buitenaf geïnspireerde 'zelf matiging en versobering. 
Naarmate traditionele instrumenten van arbeidsverhoudingen minder effectief zijn, wordt het beroep op het zelfcorrigerend vermogen van het bedrijfsleven des te groter. Dit blijkt bijvoorbeeld al vroeg uit de totstandkoming van collectieve gedragscodes, zoals de in 1972 door de International Chamber of Commerce (ICC) vastgestelde ICC Guidelines for International Investment, de OECD Guidelines for Multinational Enterprises van 1976 en de Tripartite Declaration of Principles Concerning Multinational Enterprises and Social Policy van de ILO uit 1977 (zie o.a. ILO, 2006). Sinds het einde van de jaren zeventig zijn het vooral de transnationale ondernemingen zelf die, hetzij op aandrang van NGO's, hetzij vanuit een eigen behoefte aan maatschappelijke profilering of als teken van goed werkgeverschap, het initiatief nemen tot gedragscodes op het gebied van maatschappelijk verantwoord ondernemen (corporate social responsibility, CSR). Heden ten dage beschikken de meeste multinationals over een (vorm van een) gedragscode. Deze gedragscodes hebben meestal betrekking op arbeidsnormen en arbeidsverhoudingen en zijn grotendeels afgeleid van de op dat gebied al bestaande ILO-conventies (OECD, 2000). Meer recent zijn in een aantal multinationale ondernemingen international framework agreements (IFA's) tot stand gekomen, gedragscodes die in of na overleg met de werknemers of de vakbeweging zijn vastgesteld. Voor de ILO zijn dergelijke ontwikkelingen aanleiding geweest om te speculeren over de mogelijkheid van het ontstaan van een 'framework' voor wereldwijde arbeidsverhoudingen.

Een ander type instrument betreft het indirecte en directe aandelenbezit van werknemers (vgl. Engelen, 2000). In 2006 bedroeg het gezamenlijk vermogen van de pensioenfondsen wereldwijd een slordige 2000 miljard dollar. In de VS behoren deze fondsen tot de belangrijkste kapitaalverschaffers en bezitten zij zo'n $45 \%$ van alle buiten de beurs verhandelbare aandelen. ${ }^{8}$ Nederlandse pensioenfondsen zijn belangrijke spelers op de beleggingsmarkt. Medio 2006 bedraagt het totale pensioenkapitaal in ons land 671 miljard euro. Het grootste pensioenfonds, het ambtenarenfonds ABP, beschikt over een vermogen van ruim 200 miljard euro, waarvan $36 \%$ in aandelen van beursgenoteerde ondernemingen is belegd. Het in omvang tweede pensioenfonds PGGM, het fonds voor de sector zorg en welzijn, beschikt over een vermogen van bijna 81 miljard euro, waarvan $46 \%$ in beursfondsen is belegd. Als medebestuurder van de pensioenfondsen heeft de Nederlandse vakbeweging zich enige tijd geleden al uitgesproken over een verantwoord beleggingsbeleid. In de nota 'Goed Belegd' van juli 2000 pleit de FNV ervoor niet te beleggen in landen die de mensenrechten ernstig schenden, maar vooral in die bedrijven die goed scoren op de drie P's: People, Planet, Profit. Deze beleidslijn is verder uitgewerkt in een op 8 maart 2007 verschenen FNV-nota, waarin een minder passieve rol voor de pensioenfondsen wordt bepleit en een duidelijker opstelling ten aanzien van een maatschappelijk verantwoord beleggingsbeleid. Maatschappelijk verantwoord beleggen is overigens een thema dat ook op mondiaal niveau aan de orde is. In 2006 zijn bijvoorbeeld op initiatief van de Verenigde Naties Principles for Responsible Investments opgesteld, die zijn neergelegd in een charter dat in datzelfde jaar is ondertekend door pensioenfondsen wereldwijd, inclusief de grote Nederlandse fondsen. Deze voorbeelden laten zien dat de vakbonden via hun vertegenwoordiging in de besturen van pensioenfondsen invloed kunnen uitoefenen op een groot deel van de beleggingsmarkt.

Naast het indirecte aandelenbezit van werknemers is er ook het directe aandelenbezit. Recent is berekend dat $80 \%$ van alle grotere beursgenoteerde ondernemingen in 29 Europese landen met in totaal zo'n 32 miljoen werknemers aandeelhouderschap voor werknemers (Employee Share Ownership Plans, ESOP's) heeft ingevoerd (EFES, 2008). 
In de VS bestaan 11.000 van dergelijke ESOP's, veelal gefinancierd vanuit de pensioenfondsen, waarbij zo'n tien miljoen werknemers betrokken zijn (Blasi, Kruse \& Bernstein, 2003). In die zin kan aandelenbezit van werknemers fungeren als middel tot beleidsbeïnvloeding, al was het maar in de vorm van protective ownership, als bescherming tegen vijandelijke overnames.

Het is hier niet de verwachting dat genoemde instrumenten het functieverlies volledig kunnen compenseren dat binnen de nationale arbeidsverhoudingen dreigt te ontstaan. Hooguit kunnen ze een bijdrage vormen tot wat meer bestuurlijke capaciteit op mondiaal niveau. Voor andere impulsen wordt doorgaans gerefereerd aan initiatieven van NGO's, de niet-gouvernementele organisaties op terreinen als milieu en consumentenbescherming. Het alternatief zou zijn dat de stakeholders worden blootgesteld aan een ongecorrigeerde marktwerking, met als uiteindelijke reactie een herlevend neoprotectionisme. En dat is een toekomstbeeld waarnaar op dit moment niemand met verlangen zal uitzien.

\section{Noten}

1 Vgl. Menno Tamminga, 'Ondernemen is overnemen. Vijandige en vriendschappelijke miljardendeals zijn in Europa aan de orde van de dag.' NRC Handelsblad, 25 maart 2006.

2 Aan de hand van de beschikbare data is vastgesteld dat in $200718 \%$ van de toegevoegde waarde van de lidstaten afkomstig is van bedrijven in buitenlands bezit. Daarvan is $23 \%$ van de ondernemingen eigendom van Amerikaanse bedrijven. Ruim een vijfde (21\%) van de werkgelegenheid in de industrie is afkomstig van een onderneming, die buitenlands eigendom is (Eurostat 30/2008).

3 Zie Maarten van Schinkel en Jeroen Wester, 'Alles op rood, en een fooi voor de dealer'. NRC Handelsblad, 24 februari 2007.

4 I.c. lid van het bestuur Peter Wakkie. Zie 'Multinational bezorgt OR hoofdbrekens'. Trouw, 19 januari 2007.

5 Dit betreft de werknemersleden en de kroonleden Bovens, Goudswaard, Van der Heijden, Vliegenthart en Wilke.

6 Zoals in België (vanaf 1989), Denemarken (1987), Finland (1996), Ierland (1987), Italië (1993), Portugal (1996), Zweden (1991), uiteindelijk (2007) zelfs Frankrijk.

7 Onderzoek van 21 minuten.nl. Zie: 'Terugkeer naar bescherming is uit den boze'. NRC Handelsblad, 7 december 2006.

8 Financial Times, 27 april 2006.

\section{Literatuur}

Bamber, G.J., Lansbury, R.D. \& Wailes, N. (eds.) (2004). International and Comparative Employment Relations. London: Sage.

Blanpain, R. (2002). The impact of the information society on the world of work in developed countries. In: Tadashi Hanami (ed.). Global integration and challenges for industrial relations and human resource management in the twenty-first century (pp. 35-48). The Japan Institute of Labour

Blasi, J.R., Kruse, D. \& Bernstein, A. (2003). In the company of owners. New York: Basic Books.

Buitendam, A. (2001). Verzilveren en verzekeren. Werknemersrisico's en ondernemingsbestuur. Assen: Van Gorcum.

Castells, M. (1991). The Informational City: Information Technology, Economic Restructuring and the Urban Regional Process. Cambridge, MA: Basil Blackwell.

CBS (2007). Buitenland steeds belangrijker voor werkgelegenheid in Industrie. Web magazine, 5 maart 2007. 
Cortebeeck, V., Huys, R., Van Gyes, G. \& Vandenbrande, T. (2005). The Quality of Industrial Relations Indicators: An Assessment of the Data and the Country Profiles of 15 EU Member States. Leuven: KU Leuven/European Foundation.

DNB (2005). Financiële stabiliteit: de groei van de derivatenhandel. Kwartaalbericht DNB, December 2005.

Dunlop, J.T. (1958). Industrial Relations Systems. New York: Holt.

EC (2002). Industrial Relations \& Industrial Change. Report of the High Level Group on Industrial Relations and Change in the European Union. Luxembourg: Publications Office.

EC (2004). Industrial Relations in Europe 2004. Luxembourg: Publications Office.

EC (2005). Employment in Europe 2005: Recent Trends and Prospects. Luxembourg: Publications Office.

EC (2006). Industrial Relations in Europe 2006. Luxembourg: Publications Office.

EF (2002). The Europeanization of Industrial Relations in a Global Perspective: A Literature Review. Luxembourg: Publications Office.

EF (2004). Quality in Industrial Relations: Comparative Indicators. Luxembourg: Publications Office.

EF (2007a). Restructuring and employment in the EU: The impact of globalisation. ERM report. Luxembourg: Publications Office.

EF (2007b). Impact of globalisation on industrial relations in the EU and other major economies. Luxembourg: Publications Office.

EF (2007c). Industrial relations in the EU Member States 2000-2004. Luxembourg: Publications Office.

EFES (2008). European Federation of Employee Shareholders, retrieved from http://www.efesonline.org/LIBRARY/2008.

EIRO (2000). Wage Policy and EMU. Dublin: European Foundation.

EIRO (2006). Pay developments - 2005. Dublin: European Foundation.

Engelen, W. (2000). De Burger en de Onderneming. Amsterdam: Thela Thesis.

Eurobarometer (2003). Flash Eurobarometer $151 b$.

Eurobarometer (2006). Special Eurobarometer 251.

Eurostat (2008). Foreign-controlled enterprises in the EU. Statistics in Focus, 30.

Fukuyama, F. (1992). The End of History and the Last Man. New York: Free Press.

Galgoczi, B. (2004). Changing patterns of corporate social responsibility in Europe. Paper presented at the EU-Japan Workshop on Corporate Social Responsibility. Hitotsubashi University, Tokyo, 26-27 November.

Geelhoed, L.A. (1997). Een delta in Europa. ESB, 82 (4087), 4-8.

Gereffi, G. (2005). The new off shoring of jobs and global development. Geneva: International Institute for Labour Studies.

Gonzalez-Perez, M-A. \& McDonough, T. (2007). More than Bananas: Social Responsibility Networks and Labour Relations in the Banana Industry in the Urabá Region of Colombia. In: V. Schmidt (ed.). Trade union responses to globalization. Geneva: International Labour Office.

Harman, C. (1996). Globalisation: A Critique of New Orthodoxy. International Socialism, 73. Reteived from http://www.lpi.org.uk/.

Hay, C. (2000). Contemporary Capitalism, Globalization, Regionalization and the Persistence of National Variation. Review of International Studies, 26 (4), 509-531.

Heijden, P.F. van der (2000). Nederland, de Europese Unie en medezeggenschap. Paper t.b.v. de conferentie Toekomst Nederlandse medezeggenschap in Europees perspectief. Den Haag, 6 april.

Höpner, M. (2001). Corporate Governance in Transition: Ten Empirical Findings on Shareholder Value and Industrial Relations in Germany. MPIfG Discussion Paper, 01/5.

Huiskamp, R. \& Vos, K.J. (2007). Flexibilization, Modernization and the Lisbon Strategy. International Journal of Comparative Labour Law and Industrial Relations, 23 (4), 587-599.

Hyman, R. (1975). Industrial Relations: A Marxist Introduction. Basingstoke: Macmillan.

Hyman, R. (2001). The Europeanization - or the Erosion - of Industrial Relations? Industrial Relations Journal, 32 (4), 280-94.

ILO (1994). Defending Values, Promoting Change, Social Justice in a Global Economy: An ILO Agenda. Geneva: International Labour Office.

ILO (2006). Tripartite declaration of Principles Concerning Multinational Enterprises and Social Policy. Geneva: International Labour Office.

Kerr, C., Dunlop, J.T., Harbison, F.H. \& Myers, C.A. (1960). Industrialism and Industrial Man. Cambridge Mass.: Harvard University Press.

Kol, J. (2001). Wat is globalisering en tot hoever is het wenselijk? ESB, 86 (4331), 816-819. 
Macdonald, D. (1997). Industrial Relations and Globalization: Challenges for Employers and their Organizations. Paper presented at the ILO Workshop on Employers' Organizations. Turin, 5-13 May.

Müller-Jentsch, W. (1997). Soziologie der industriellen Beziehungen. Eine Einführung. Frankfurt/ Mannheim: Campus.

OECD (2000). Codes of Corporate Conduct - An Expanded Review of their Contents. (TD/TC/ WP(99)56/FINAL). Paris: OCED.

OECD (2007). Globalisation, Jobs and Wages. Policy Brief, June 2007.

Prodi, R. (2003). Europe: the dream and the choices. Bulletin Quotidien Europe, 21 (November, no. 22339/2340).

Reich, S. (1998). What is Globalization? Four Possible Answers. University of Pittsburgh Working Paper, 261.

Ruigrok, W. \& Tulder, R. van (1995). The Logic of International Restructuring. London/New York: Routledge.

Scharpf, F.W. (2002). The European Social Model: Coping with the Challenges of Diversity. MPfG Working Paper, 02/8.

Schilstra, K. \& Smit, E. (2005). Voeten op de vloer. Strategische keuzes in de belangenbehartiging van werknemers. Amsterdam: Aksant.

Seifert, H. \& Tangian, A. (2007). Flexicurity: Reconciling Social Security with Flexibility - Empirical Findings for Europe. WSI-Diskussionspapier, 154.

SER (2008). Advies Evenwichtig Ondernemingsbestuur. Den Haag: SER.

Streeck, W. (1998). The internationalization of industrial relations in Europe: prospects and problems. Working Paper Series in European Studies, 1 (1).

Tangian, A. (2006). Monitoring flexicurity policies in Europe from three different viewpoints. WSIDiskussionspapier, 145.

UNCTAD (2006). World Investment Report 2006. FDI from Developing and Transition Economies: Implications for Development. New York/Geneva: United Nations.

Van Apeldoorn, B. (2001). The struggle over European order: transnational class agency in the making of 'Embedded Neoliberalism'. In: A. Bieler \& A.D.Morton (eds.). Social Forces in the making of new Europe: the restructuring of European social relations in the global political economy. (pp. 70-89). Basingstoke: Palgrave.

Veen, R. van der (2004). Nieuwe risico's en oude arrangementen. In: J. van Hoof \& W. van Noort (red.). Arbeid, onderwijs, sociale ongelijkheid in de 21e eeuw. Amsterdam: Boom.

Visser, J. \& Hemerijck, A. (1998). Een Nederlands Mirakel. Beleidsleren in de verzorgingsstaat. Amsterdam: Amsterdam University Press.

Vitols, S. (2005). Prospects for trade unions in the evolving European system of corporate governance. Brussels: European Trade Union Institute (ETUI-REHS).

Vos, K.J. (2006). Europeanization and Convergence in Industrial Relations. European Journal of Industrial Relations, 12 (3), 311-327.

Vos, K. (2007). European Convergence and the EU Social Model. In: P. Leisink, B. Steijn \& U. Veersma (eds.). Industrial Relations in the new Europe (pp. 23-39). Cheltenham: Edward Elgar.

Welsum, D. van \& Vickery, G. (2005). Potential off shoring of ICT-intensive using occupations. DSTI Information Economy Working Paper, STI/ICCP/IE(2004)19/FINAL.

Wester, J. (2008). Help! We worden overgenomen. Amsterdam/Rotterdam: Prometheus/NRC Handelsblad.

World Commission on the Social Dimension of Globalization (2004). A Fair Globalization: Creating Opportunities for All. Geneva: International Labour Office. 